DOI: $10.14451 / 2.131 .31$

\title{
НЕТИПИЧНЫЕ НОРМАТИВНЫЕ ПРЕДПИСАНИЯ В НАЛОГОВОМ ПРАВЕ
}

\author{
(c) 2019 Сапрыкина Ирина Анатольевна \\ кандидат юридических наук, доцент кафедры финансового права, юридический факультет \\ Воронежский государственный университет, Россия, Воронеж \\ E-mail: irina-saprykina@rambler.ru
}

Традиционно основной формой регуляции общественных отношений признается норма права. Вместе с тем в механизме правового регулирования важную роль выполняют нетипичные нормативные предписания. В налоговых отношениях в настоящее время наблюдаются особенности действия таких нетипичных предписаний, как презумпции, фикции, дефиниции, принципы и аксиомы, юридические конструкции и оперативные предписания. В статье автором проводится анализ их роли и значения.

Ключевые слова: норма права; структура нормы права; нетипичные нормативные предписания в налоговом праве; презумпции; фикции; дефиниции; принципы и аксиомы в праве; юридические конструкции; оперативные предписания

Политическое, экономическое и социальное развитие общества предполагает повышение требований к состоянию юридической культуры действующего законодательства и правоприменительной практики. В последние десятилетия в нашей стране актуализировался вопрос налоговой культуры. Динамично развивающееся законодательство о налогах и сборах и обширная практика налогового правоприменения требуют нового осмысления отдельных разновидностей нормативных предписаний, определение их роли и значения в структуре налогово-правового регулирования.

В праве существует обособленная группа нетипичных нормативных предписаний, которая не подвергалась комплексному правовому исследованию". Зачастую нетипичные нормативные предписания рассматриваются в качестве разновидности правовой нормы. Однако можно предположить, что нетипичные предписания по некоторым признакам будут отличаться от типичных норм. По мнению Е.Г. Лукьяновой, «норма права имеет двойственный, предоставительно-обязывающий (управомочивающе-обязывающий) х характер. Предоставительно-обязывающий характер означает, что норма права, являясь правовым правилом поведения, устанавливает меру возможного (свободного) и должного поведения субъектов общественных отношений, другими словами, закрепляет за субъектами их взаимные субъективные права и юридические обязанно- сти» [6, С. 69-70]. По мнение автора, если правовое предписание не обладает указанным свойством, то его нельзя относить к нормам права. Иными словами, структура нормы права должна иметь стандартную схему «гипотеза-диспозициясанкция». Нетипичные нормативные предписания такой структурой не обладают, но вместе с тем они играют важную роль в формировании и функционировании системы права. При сравнении нормы права и нетипичного нормативного предписания можно наблюдать как сходные характеристики, так и отличительные особенности. На особенности нетипичных нормативных предписаний указывал В.М. Горшенев. По его мнению, «не все нормативные предписания государства представляют собой классическую модель нормы права и потому нет достаточных оснований отождествлять многие из них с нормой права» [2, С. 113]. В литературе нетипичные нормативные предписания именуются специализированными нормами, что указывает на их особое значение. Отмечается, что «современное правовое регулирование становится эффективным именно благодаря сочетанию в нормативном материале как типичных, так и нетипичных норм права» [5, С. 204].

Схожими для нормы права и нетипичного нормативного предписания выступают признаки общеобязательности и общепризнанности, системности и связанности с другими правилами поведения. Однако нельзя утверждать, что нетипичным нормативным предписаниям

* В финансовом праве чаще всего исследуются только отдельные виды норм права. В качестве примеров см. [7; 9; 3]. 
присущи характеристики установления только компетентными государственными органами и обеспечения реализации таких правил принудительной силой государства.

Анализ законодательства о налогах и сборах, прежде всего Налогового кодекса РФ (далее - НК РФ), судебных актов и сформулированных в них налоговых правовых позиций показывает, что в налогово-правовом регулировании достаточно часто применяются нетипичные нормативные предписания. К их числу относятся презумпции и фикции, дефиниции, принципы и аксиомы, юридические конструкции, оперативные предписания.

Презумпции в налоговом праве. В переводе с латыни «презумпция» (praesumptie) означает «предполагаю», «ожидаю». Как правовой термин она заключает в себе предположение, гипотезу, подтверждение или опровержение которой должно служить средством установления искомых обстоятельств, юридических фактов и их следствий [10, С. 98]. В правовом регулировании презумпции используются в разных значениях: как вид нормы права, юридический факт, прием законодательной техники, юридический метод. В налоговом праве велика роль общеправовых презумпций (презумпция невиновности, презумпция знания действующего закона, презумпция правосубъектности участников отношений, презумпция конституционности действующего нормативного акта и др). Они не всегда воспроизводятся в законодательстве о налогах и сборах, но следуют из его смысла. Некоторые общеправовые презумпции все же получили свое закрепление в НК РФ. Так, устанавливается презумпция невиновности налогоплательщика: «лицо считается невиновным в совершении налогового правонарушения, пока его виновность не будет доказана в предусмотренном законом порядке» [12]. В налоговом праве презумпция невиновности имеет следующую интерпретацию. Налогоплательщик считается невиновным, пока его виновность в совершении налогового правонарушения не будет установлена. Обязанность доказать виновность налогоплательщика возлагается на налоговые органы. Все неустранимые сомнения, противоречия и неясности актов законодательства о налогах и сборах толкуются в пользу налогоплательщика.

Презумпция конституционности действующего налогового закона гораздо чаще остальных ставилась под сомнение. На это указывают мно- гочисленные обращения налогоплательщиков в КС РФ с требованием признать налоговую норму неконституционной.

Презумпция содержится и в ст. 40 НК РФ, в соответствии с которой, пока не доказано обратное, предполагается, что цена для целей налогообложения соответствует уровню рыночных цен. При применении налогоплательщиком системы налогообложения в виде единого налога на вмененный доход для отдельных видов деятельности применяется презумпция получения дохода налогоплательщиком.

Налоговые презумпции были сформулированы судебными доктринами. Пленум ВАС РФ в Постановлении от 12 октября 2006 г. № 53 «Об оценке арбитражными судами обоснованности получения налогоплательщиком налоговой выгоды» указал, что судебная практика при разрешения налоговых споров исходит из презумпции добросовестности налогоплательщиков и иных участников правоотношений в сфере экономики. В связи с этим предполагается, что действия налогоплательщика, имеющие своим результатом получение налоговой выгоды, экономически оправданны, а сведения, содержащиеся в налоговой декларации и бухгалтерской отчетности,- достоверны [13].

НК РФ можно дополнить и другими презумпциями, в частности, презумпцией добросовестности и разумности при исполнении функций публичного характера должностными лицами налоговых органов.

Фикции в налоговом праве. Правовая фикция - это не существующее положение, но в силу определенных обстоятельств признаваемое законодателем как реальное, существующее и ставшее в силу этого обязательным [4, С. 188]. Считается, что главной особенностью фикции является то, что она носит неопровержимый характер.

Существуют следующие примеры фикций в налоговом праве. Ст. 11 НК РФ содержит понятие организации. В гражданском праве разработана теория фикции юридического лица, согласно которой юридическое лицо есть искусственная конструкция, придуманная законодателем. Юридическое лицо наделено правами и обязанностями, которые фактически осуществляют и исполняют конкретные физические лица. Примерами фикцией в налоговом праве являются взаимозависимые лица (ст. 105.1 НК РФ) и контролируемые иностранные компании 
(ст. 25.13 НК РФ). В налоговых отношениях все чаще используются электронные документы и электронные цифровые подписи как юридические фикции (ст. 11.2 НК РФ). Налоговому праву известна процессуальная фикция объявления гражданина умершим. Обязанность по уплате налога прекращается со смертью физического лица - налогоплательщика или с объявлением его умершим (ст. 44 НК РФ). В налоговом законодательстве содержатся «опережающие» фикции: «если окончание срока приходится на месяц, в котором нет соответствующего числа, то срок истекает в последний день этого месяца» (ст. 6.1. НК РФ). Часто в рамках НК РФ используется фикция, в соответствии с которой документ считается полученным налогоплательщиком по истечении определенного срока, хотя в действительности факт такого получения может отсутствовать. К примеру, в случае направления налогоплательщику требования об уплате налога по почте заказным письмом оно считается полученным по истечении шести дней с даты направления заказного письма (п. 6 ст. 69 НК РФ).

Дефиниции в налоговом праве. Дефинитивные предписания фиксируют юридические понятия. Юридическая природа дефиниции состоит в том, что она находит четкое закрепление в правовом акте [2, С. 117]. В праве существуют категории, которые не могут не иметь законодательной формулировки. К примеру, ст. 8 НК РФ содержит понятие налога. Другие обязательные платежи, не обладающие признаками, перечисленными в данном определении, налогами не являются. Существуют общеправовые категории, которые требуют конкретизации в отраслевом законодательстве. Согласно ст. 11 НК РФ институты, понятия и термины гражданского, семейного и других отраслей законодательства, используемые в НК РФ, применяются в том значении, в каком они используются в этих отраслях законодательства, если иное не предусмотрено НК РФ. НК РФ, к примеру, содержит понятие «иностранная структура без образования юридического лица», известное только налоговому законодательству. Его определение преследует цель придания иностранным структурам статуса налогоплательщика.

От того, на сколько точно законодателем дана формулировка понятия, зависит дальнейшее успешное применение дефиниции. Ярким примером является «объект налогообложения». Ст. 38 НК РФ, содержащая определение данного понятия, множество раз корректировалась, так как вызывала сложности в практике применения. Дело в том, что законодатель для формулировки избрал способ перечисления фактов хозяйственной деятельности налогоплательщика, которые могут служить основанием налогообложения. Постоянная потребность государства в финансовых ресурсах обусловила такое максимально широкое содержание объекта налогообложения. В части второй НК РФ объекты налогообложения конкретизируются по отдельным видам налогов. Зачастую общие и специальные характеристики объекта налога противоречат друг другу, наблюдается разница в их правовой и экономической трактовке.

Принципы налогового права. Это выраженные в праве исходные нормативно - руководящие начала, характеризующие его содержание, его основы, закрепленные в нем закономерности общественной жизни [1, С. 75]. Теоретики права говорят о направляющем значении принципов права. Принципы налогового права закреплены в НК РФ (ст. 3 НК РФ). Это, к примеру, принципы всеобщности и равенства налогообложения, экономического основания налога и др. Они являются отраслевыми принципами. Принципы налогового права формулируются в ряде случаев судебными доктринами (принцип единой финансовой политики, включая налоговую, принцип единства налоговой системы и др.). Налоговые отношения находятся также под воздействием общеправовых принципов (законности, справедливости, гуманизма и др.), хотя они прямо не закреплены в НК РФ. Принципы налогового права играют основную роль в устранении пробелов в праве, на их основе рассматривается и разрешается налоговый спор при отсутствии в законе нормы права.

Аксиомы в налоговом праве. Аксиомы часто характеризуются совместно с правовыми принципами, находятся с ними поблизости. Аксиомы и принципы права - это конкретизирующие сущность права, основополагающие начала, идеи, лежащие в основе системы правовых норм - объективного права [6, С. 53]. Наличие в праве аксиом позволяет сделать более эффективным правовое регулирование. Примеры аксиом в праве: «нельзя быть судьей в своем деле», «судья знает право, закон», «более суровый закон не имеет обратной силы». Как видно из приведенных примеров, формулировки аксиом схожи с формулировками принципов права. Основное 
отличие аксиом от принципов состоит в том, что они изначально формулируются правовой доктриной, а в последующем получают закрепление в законодательстве. Налоговая аксиома содержится в ст. 5 НК РФ, в соответствии с которой акты законодательства о налогах и сборах, устанавливающие новые налоги, повышающие налоговые ставки или иным образом ухудшающие положение налогоплательщиков, обратной силы не имеют. Она выступает важной гарантией прав налогоплательщиков. При проведении мероприятий налогового контроля возможно использование свидетельских показаний. Не могут допрашиваться в качестве свидетеля лица, которые получили информацию, необходимую для проведения налогового контроля, в связи с исполнением своих профессиональных обязанностей (ст. 90 НК РФ).

Юридические конструкции в налоговом праве. Рудольф фон Иеринг называет юридические конструкции высшей юриспруденцией [8, С. 68]. Сами по себе юридические конструкции представляют собой модель, обобщающую наиболее существенные элементы сложного по своему составу и одновременно единого целого правового явления или состояния. Будучи своеобразной типовой, обобщающей структурой, юридические конструкции имеют целью экономию затрат сил в юридической практике и в тоже время вносят в нее определенность, четкость [2, С. 118]. В налоговом праве самой известной конструкцией является юридическая конструкция налога, хотя в законодательстве о налогах и сборах этот термин не употребляется. В соответствии со ст. 17 НК РФ юридическая конструкция налога представлена налогоплательщиком (субъектом налога) и элементами налогообложения, к которым относятся объект налогообложения, налоговая база, налоговый период, налоговая ставка, порядок исчисления налога, порядок и сроки уплаты налога. Налог считается установленным, если применительно к нему определены все составляющие юридической конструкции налога.

Оперативные предписания в налоговом праве определяют момент и порядок вступления в силу того или иного нормативного акта, пролонгируют действие нормативного акта на новый срок, распространяют действие нормативного акта на новые общественные отношения или отменяют действие нормативного акта [5, С. 204-205]. Оперативные предписания содержатся в НК РФ и Федеральных законах о введении в действие части первой и части второй НК РФ. Особенностью оперативных налоговых предписаний является то, что они устанавливают общие для всех налоговых отношений правила. Оперативное предписание предусматривает, что акты законодательства о налогах и сборах вступают в силу не ранее чем по истечении одного месяца со дня их официального опубликования. Вступление акта в силу не сразу после его опубликования, а по истечении определенного срока имеет важное значение. Это позволяет гражданам, должностным лицам уяснить его содержание, пока акт еще находится в состоянии «бездействия», сообразовать с ним свое поведение [11, С. 195].

$$
\text { **** }
$$

Динамично развивающееся законодательство о налогах и сборах должно увеличивается не только количественно, но и приобретать новые качественные характеристики. Этому способствует включение в его состав нетипичных нормативных предписаний, которые могут дать новые тенденции развития налоговому праву, налоговым судебным доктринам и процессу налогового правоприменения. Научное осмысление нетипичных нормативных предписаний ярче подчеркнет связь науки с юридической практикой.

\section{Библиографический список}

1. Алексеев С. С. Общая теория права: учеб.-2-е изд., перераб. и доп.-М.: Проспект, 2009.-576 с.

2. Горшенев В.М. Нетипичные нормативные предписания в праве // Советское государство и право. 1978 . № 3. С. 113-118.

3. Демин А.В. Общая теория налогово-правовых норм: Монография.-М.: РИОР: ИНФРА-М, 2013.-266 с.

4. Кашанина Т.В. Юридическая техника: учебник / Т.В. Кашанина.-М.: Эксмо, 2007. - 512 с.

5. Лазарев В.В., Липень С. В. Теория государства и права: Учебник для вузов.- М.: Издательство «Спарк», 1998. $448 \mathrm{c.}$

6. Лукьянова Е.Г. Теория права и государства. Введение в естественно-правовой курс: учеб. пособие / Е.Г. Лукьянова.- М.: Норма: ИНФРА-М, 2011.- 208 с. 
7. Пауль А. Г. Процессуальные нормы бюджетного права / Под общ. ред. М.В. Карасевой. - СПб.: Питер, 2003. 208 c.

8. Рудольф фон Иеринг: Юридическая техника / Сост. А.В. Поляков.- М.: Статус, 2008. - 231 с.

9. Сапрыкина И.А. Процессуальные нормы налогового права: Автореф. дисс. ... канд. юрид. наук. Воронеж, 2009. - 23 с.

10. Черниловский 3.М. Презумпции и фикции в истории права // Советское государство и право. 1984 . № 1. С. 98-105.

11. Юридическая техника: учебное пособие по подготовке законодательных и иных нормативных правовых актов органами исполнительной власти / Ин-т законодательства и сравн. правоведения при Правительстве РФ; под. ред. Т.Я. Хабриевой, Н.А. Власенко.- М.: Эксмо, 2010.- 272 с.

12. Ст. 108 Налогового кодекса РФ

13. Вестник Высшего арбитражного суда РФ. 2006. № 12. 